\title{
Brazilian Corn Exports: An Analysis of Cargo Flow in Santos and Paranagua Port
}

\author{
Aguinaldo Eduardo de Souza *1,2,6 , João Gilberto Mendes dos Reis 1,3,6, \\ Emerson Rodolfo Abraham ${ }^{1,4}$, and Sivanilza Teixeira Machado 5 \\ 1 Paulista University - UNIP, PPGEP, São Paulo, Brazil \\ 2 UNIBR, São Vicente, Brazil \\ 3 UFGD, PPGA, Dourados, Brazil \\ 4 Metodista University, São Bernardo do Campo, Brazil \\ 5 Federal Institute of São Paulo, Suzano, Brazil \\ 6 CEETEPS, College of Zona Leste and Baixada Santista \\ *Corresponding author: souza.eduaguinaldo@gmail.com
}

\begin{abstract}
The world's population is projected to increase to 9 billion till 2050 , increasing feed demand. Corn is one of the most important grains in food supply chains (FSC), and growers have an essential role. This article aims to investigate the flow of Brazilian corn among origin, main ports, and international markets to address a panorama of corn production in Brazil. With this objective, we collected data from the Brazilian Ministry of Industry and Foreign Trade, and we analyzed this data using Social Network Analysis (SNA) tools. The results showed that corn exports in Brazil use two main ports, with Santos being the most important one.
\end{abstract}

Keywords: Logistics · Corn production - Exports - International market.

\section{Introduction}

It is forecasted that the world trade of corn will reach newer heights, boosted by a stronger demand for feed. Currently, the United States and China are the main growers, but Brazil has been considered a new frontier and occupies the third place [1]. Despite the important role of China in production, over the last five years, around $83 \%$ of export was associated with the US, Brazil, Argentina, and Ukraine. This distinctly indicates a huge internal market in China and the potential business opportunities for producers in the US and Brazil.

The United Nations expects the world population to increase to 9,725 billion by 2050 [2]; this implies a challenge for the global leaders to raise food production and at the same time to preserve the environment and local market production. In this manner, Brazil appears to be a major player in commodity production to feed the world. In case of corn, for instance, projections show an increase in Brazilian exports of $52.4 \%$ until 2026. In numbers, the country is expected to reach 46.3 million metric tonnes $(\mathrm{mt})$ per year [3].

Although Brazil has high productivity and a high quantity of available land, the flow of commodities export depends on few routes and ports that entail 
logistics bottlenecks. For example, Reis et al. [2] argue that poor logistics of Brazilian infrastructure increases the inland freight of soybean in comparison with the US by $146 \%$. Moreover, Galvão et al. [4] [5] showed that Brazilian ports cargo flow grew significantly, around $42 \%$ from 2001 to 2011, reaching 886 million (mt) in 2011; this was mainly solid bulk cargo.

Regarding Brazilian ports, Santos (Sao Paulo) and Paranagua (Parana) are the major corn exporters with 66.5 million $(\mathrm{mt})$ between 2012 and 2016. The corn flow concentration creates logistics bottlenecks such as extensive truck lines to unload cargo and low static storage capacity. Rodrigues [6] affirms that logistics management adopts a systematic cost approach based on parameters such as cost, time, and service quality level. Therefore, analyzing the flow of corn production is very important for developing a plan to improve the logistics infrastructure of major corridors.

This article aims to analyze the Brazilian corn routes and exports for understanding the current scenario and for providing knowledge to develop future plans for improving logistics operation. Thus, we address the flows of corn among the six main growers of the country to two main ports of Brazil and to the international market.

\section{Brazilian Ports}

Brazil has a continental dimension with an extensive coastline; for this reason, sea shipping is relevant to the social and economic development of the country [4]. Brazilian port sector is divided into two categories: first, the port sector that is composed of 37 seaports, managed by the federal government; the second category that is composed of 122 inland port facilities management by the Ministry of Transport [7].

The cargo flow in Brazil's seaports, in 2016, was 998,068 million (mt), where the main international traffic was dry bulk of upto 628,700 million (mt); liquid bulk of upto 218,000 with million (mt); general cargo of upto 51,300 million (t); and containers of up to 100,100 million (mt) [9].

\subsection{Santos Port}

Santos is Brazil's larger port. In 2006, it represented around $28.5 \%$ of the balance of trade of the country. Its operations reached 113.8 million $(\mathrm{mt})$ [10]. This suggests the great relevance of Santos Port among the 37 Brazilian ports. Nowadays, it is the main port of the country with 4,520 ships being docked in 2016 . Furthermore, this port is considered as being one of the biggest ports in Latin America in terms of container flow in 2015 [11].

Accessibility is the main factor that attracts cargo to the Santos Port. The port has a link with the main roadways. Moreover, it is connected to TieteParaná inland waterways by railway that facilitates a large-scale movement of commodities. 
In addition, the areas dependent on Santos Port represents 67\% of Brazilian GDP including states such as Sao Paulo, Minas Gerais, Mato Grosso, Mato Grosso do Sul, and Goias e o Distrito Federal. These states are responsible for $56 \%$ of Brazilian balance of trade [10].

\subsection{Paranagua Port}

According to the Administration of Paranagua Port and Antonina - APPA [12], the Paranagua Port has 3,581 meters of wharfs and 23 berths. It is among the five main Brazilian ports in relation to the flow of goods. The port in 2016 moved 45,045 million (mt), and it has the capacity to receive 1,909 vessels. The three main cargo were as follows: containers $(8,231$ million $(\mathrm{mt}))$, fertilizers $(8,227$ million $(\mathrm{mt}))$, and soybean $(7,950$ million $(\mathrm{mt}))$ [9].

Additionally, the Paranagua port's balance of trade was around $7.6 \%$, immediately after Santos, which, as mentioned earlier, lead the ranking with a striking difference of $28.5 \%$ [10].

\section{Methodology}

For understanding the flow of Brazil's corn exports and the role of Santos Port (Sao Paulo state), we conducted an exploratory research and comparison between the Santos Port and the major Brazilian port competitor, Paranagua. The Fig. 1 displays the location of these ports and the main origin routes.

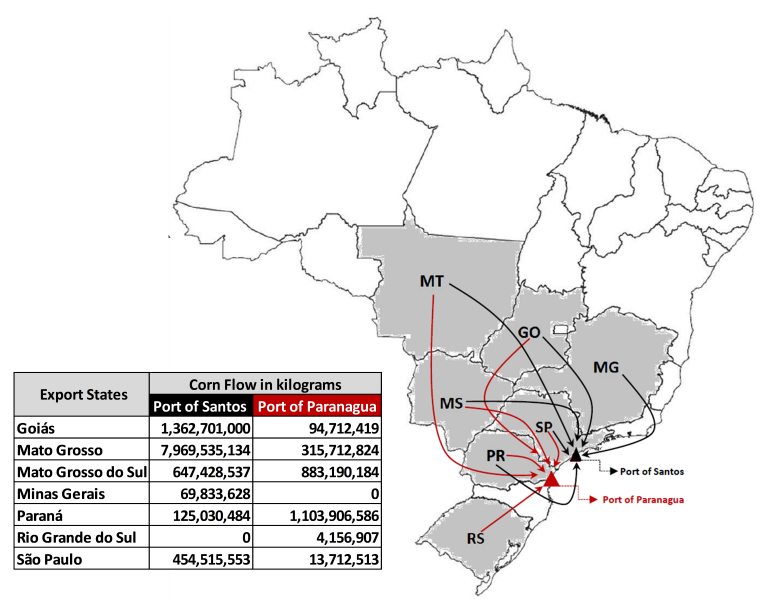

Fig. 1: Main Corn Corridors 2016

Santos and Paranagua were chosen because they represent around $50 \%$ of volume exported by the country. To perform this study we follow the following three steps: 
First: Data Collection. Data were collected from the Brazilian Ministry of Industry and Foreign Trade, using the Foreign Trade Information Analysis System (ALICEWEB). The Aliceweb provided us information regarding the volume of corn exported by grower states such as Goias, Parana, Sao Paulo, Minas Gerais, Mato Grosso do Sul, Rio Grande do Sul, and Mato Grosso.

Second: database procedure. We selected ten major destinations for Brazil's corn as per the state of origin. This allowed us to observe 38 relations among players. The data were organized considering the state of origin, the port of origin, and the country of destination. The relationships were created considering the corn flow of growers to the ports and them to countries.

Third: Analysis Using the Social Network Analysis (SNA) tools, Ucinet 6.0 and Netdraw plotted the graphs of the corn networks considering exports flow using Santos Port, Paranagua Port, and both of them together. This helped us to create a flow map regarding the corridors of exportations and also to analyze corn traffic.

\section{Results}

Santos and Paranagua ports are established as major corridors for corn exports in Brazil. Both moved around 66.5 million (mt) between 2012 and 2016 (Fig. 2). Together, Santos and Paranagua Ports deal with $81.48 \%$ and $18.52 \%$ of Brazil's corn respectively.

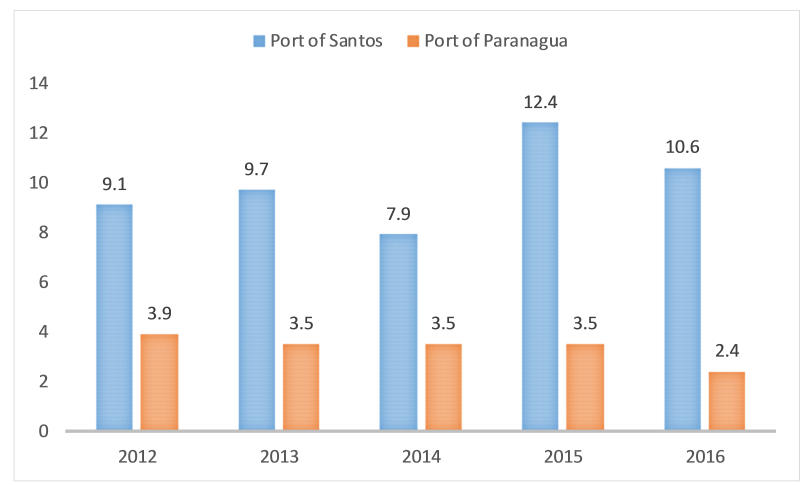

Fig. 2: Cargo Flow in Million of Metric Tonnes to Santos and Paranagua Ports (Source: Adapted of [13]).

The origin of cargo flow can be observed in Mato Grosso, Mato Grosso do Sul, Goias, Parana, Minas Gerais, and Sao Paulo e Rio Grande do Sul. As mentioned earlier in the methodology section, the volume of corn among these states and Ports of Santos and Paranagua are organized in Microsoft Excel and are entered in the Ucinet 6.0 software. Using the module Netdraw was possible 
to provide that networks to infer some analysis presented in the next subsections.

\subsection{International Traffic Considering Both Ports}

The Fig. 3 depict the corn flow considering the network as a whole, including all the states, ports, and destination. Herein, we gather the countries of destination in the continents to facilitate visualization.

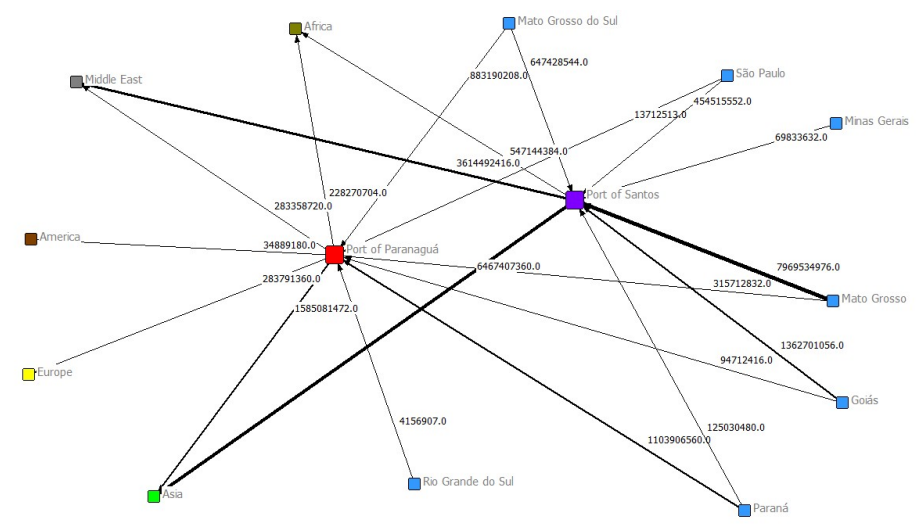

Fig. 3: Corn Flow among Brazilian States, Ports of Santos and Paranagua, and Continents of Destination

As can be seen in Fig. 3, Mato Grosso is the main grower with 8,285 million (mt) flowing to Santos and Paranagua. The distance that needs to be covered to reach both ports is almost the same, but the Santos route, especially the railroad service, is more developed than the Paranagua route. As a result, this is directly responsible for the highest cargo flow to Santos.

On the other hand, Mato Grosso do Sul represents the second volume of corn to be exported, with 1,530 million (mt) distributed equitably between both ports. The geographical position of the state with a dependence of roadway transportation allows Mato Grosso do Sul to use the ports indistinctly. They are located at the same distance of about 1,100 kilometers.

The destination of Brazilian corn as per continent was also analyzed. Our results indicate the following percentages: Asia (61.73\%), Middle-East $(29,88 \%)$, Africa $(5,94 \%)$, Europe $(2,18 \%)$, and America $(0,27 \%)$. Vietnam boosted the flow in Asia, while the Middle-East distinctly depended on import of agricultural products, both constituting the most important markets of Brazil.

\subsection{Santos}

The Fig. 4 depicts the corn flow considering the network of Santos Port. 


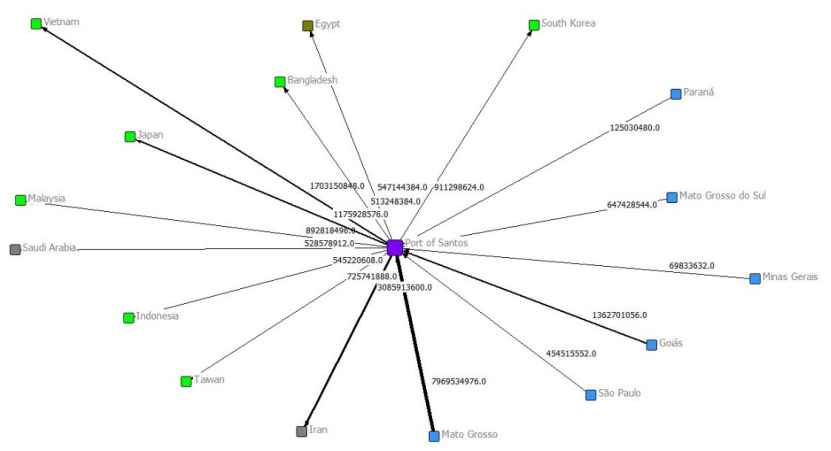

Fig. 4: Corn Flow by Santos Corridor

Santos moved 10,629 million ( $\mathrm{mt}$ ) of corn in 2016. The main exporters via Santos were Mato Grosso (74.98\%), followed by Goias (12.82\%), Mato Grosso do Sul (6.09\%), São Paulo (4.28\%), Parana (1.18\%), and Minas Gerais (0.66\%). It is possible to note that despite $60.85 \%$ of the volume being exported to the Asian continent (Taiwan, Indonesia, Japan, Vietnam, South Korea, and Bangladesh), Iran and Middle-East were highlighted within $29.03 \%$ of the volume of corn exported by Santos.

\subsection{Paranagua}

The Fig. 5 depicts the corn flow considering the network of Paranagua Port.

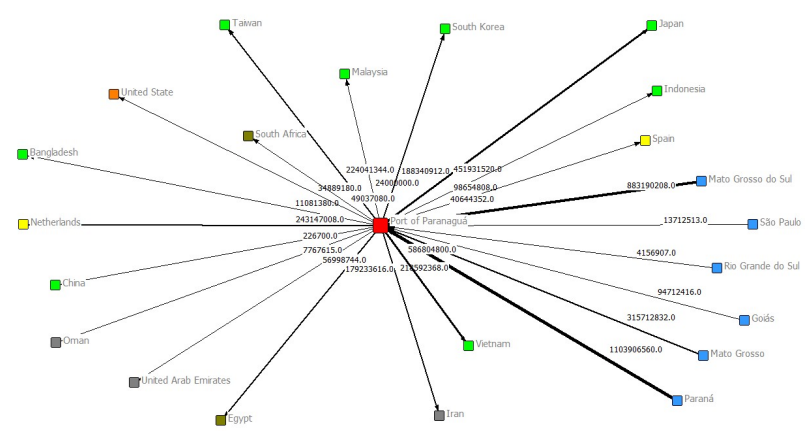

Fig. 5: Corn Flow by Paranagua Corridor

Based on Fig. 5, it is noticeable that Paranagua, in 2016, exported 2,415 million (mt). The state of Parana $(45.70 \%)$ lead the export, followed by Mato Grosso do Sul (36.57\%) and Mato Grosso (13,07\%). Among the 16 main buyers highlighted were Vietnam (24.29\%) and Japan (18.71\%). Other states represent $57.0 \%$ of imports. In relation to continents, the most important were Asia 
(65.62\%), followed by Europe (11.75\%), Middle-East (11.73\%), Africa (9.45\%), and America (1.44\%).

\section{Discussion}

We found that Santos Port is the major corridor that exports Brazilian corn production with a cargo volume that is almost three times more than that of Paranagua. Santos is undoubtedly the biggest port of Latin America, and it has the largest infrastructure associated with the main Brazilian corridors of commodities exports.

However, despite the advancement of the Port Modernization Act (8630, of 1993) and the new regulatory framework of the port sector $(12.815$, of 2013) that have the objective of providing more agility and modernizing the sector, reducing the costs of transactions $[4,5]$, port infrastructure and the quality of services remain issues that affect the agricultural production of the country [14]. According to data by the World Economic Forum pertaining to the Brazilian port infrastructure, compared with the main exporters of corn and soybeans, Brazil was the 122nd position among 144 evaluated countries [14].

Our current findings expand previous work regarding the Brazilian agribusiness sector and logistics infrastructure; this allows the identification of the corn flow to the main international markets of Brazil using quantitative data.

In spite of this article being an exploratory analysis, it permits the identification of a pathway for future studies to improve the bulk of cargo flow. The results showed that Santos and Paranagua are the main routes of corn exports and constitute a logistics operations bottleneck for the international traffic of this important feed. This is especially true for Santos because it is the major exporter of commodities and many other products. It is also Brazil's main access to the international market.

Some authors such as Marlow and Casaca [15], Vieira et al. [16] and the Brazilian National Transport Confederation [14] identified many issues that make exporting difficult; further, they provided the following aspects and opportunities to improve Santos Port: (i) Maritime access: Lack of dredging and overthrow of access channels and docking berths making access of large ships difficult; (ii) Territorial Access: Traffic jam and limited availability of railroads; (iii)Low productivity: Obsolete equipment and lack of availability of equipment and facilities; Burocracy: Greater agility in cargo clearance at ports, mooring, single window paperless port to boost delivery of documents; Information flow: Multiple systems to manage the operations, loss-making media channel, hindering the customer response time.

\section{Conclusions and Outlook}

The objective of this study was to describe the logistical corn flow of exports; moreover, it was possible to conclude that the Midwestern region was the main corn export region of Brazil. Additionally, it was noticeable that the flow of 
grain to the international market is concentrated in Santos and Paranaguá. It was also found that Asia is the main destination for exports of corn, followed by the Middle East. However, Iran is the largest purchaser of Brazilian corn followed by Vietnam.

Finally, the concentration of two routes generates logistics bottlenecks in both ports creating a traffic jam, low static capacity, and overuse of the port capacity. Thus, the subsequent studies will concentrate on simulating the capacity of Santos and Paranagua Ports to lead with commodities exports and opportunities to improve Brazilian logistics infrastructure.

\section{References}

1. International Grains Council: Five year global supply and demand projections. Tech. rep., London (2016)

2. Reis, J.G.M.d., Vendrametto, O., Naas, I.d.A., Costabile, L.T., Machado, S.T.: Avaliação das estratégias de comercialização do milho em ms aplicando o analytic hierarchy process (ahp). Revista de Economia e Sociologia Rural 54(1), 131-146 (2016)

3. Ministry of Agriculture, Livestock and Food Supply: Projections of agribusiness brazil 2015/2016 a 2025/2026. Tech. rep., Brasília (2016)

4. Galvão, C.B., Robles, L.T., Guerise, L.C.: The Brazilian seaport system: A post-1990 institutional and economic review. Research in Transportation Business \& Management 8, 17-29 (2013)

5. Farranha, A.C., da Silveira Frezza, C., de Oliveira Barbosa, F.: Nova lei dos portos: desafios jurídicos e perspectivas de investimentos. Revista Direito GV 11(1), 089 (2015)

6. Rodrigues, P.R.A.: Introdução aos sistemas de transporte no Brasil e à logística internacional. Edições Aduaneiras, São Paulo (2008)

7. Ministério dos Transportes, Portos e Aviação Civil: http://www. portosdobrasil. gov.br/assuntos-1/sistema-portuario-nacional

8. INOPLAN: http://www.nitdesk.com.br/ports/\#about

9. Agência Nacional de Transporte Aquaviário: Desempenho do setor aquaviário 2016. oportunidades e melhorias portuárias. Tech. rep., Brasília (2016)

10. Companhia Docas do Estado de São Paulo: Análise do movimento físico do porto de santos. Tech. rep., São Paulo (2016)

11. Comissão Economica para América Latina e Caribe: http://www.cepal.org/es/ infografias/ranking-puertos-top-20-america-latina-caribe-2015

12. Administração dos Portos de Paranaguá e Antonina: Porto em números administração dos portos de paranaguá e antonina 2011-2015. Tech. rep., Paranaguá (2016)

13. ALICEWEB: http://aliceweb.mdic.gov.br//consulta-ncm/index/type/ exportacaoNcm

14. Confederação Nacional do Transporte: Transporte e desenvolvimento. entraves logísticos ao escoamento de soja e milho (2015)

15. Marlow, P.B., Casaca, A.C.P.: Measuring lean ports performance. International journal of transport management 1(4), 189-202 (2003)

16. Vieira, G.B.B., Neto, F.J.K., Ribeiro, J.L.D.: The rationalization of port logistics activities: A study at port of santos (Brazil). International Journal of e-Navigation and Maritime Economy 2, 73-86 (2015) 